use. When these in their turn were left behind, water was carried in tins and captured enemy watercontainers. Older men who experienced the chlorinated water of the War of 1914-18 will realize what lies behind the sober account of these vital matters given by Colonel Gear. They will also be interested to hear that the sun topee was abandoned without bad results. Perhaps they will remember the friends who visited their Mesopotamian messes and next day were dead from the sudden 'effects of heat'. They will be glad to hear that no cases of heat- or sunstroke or of other direct effects of heat were reported in the Western Desert. Even the tanks did not require special air-conditioning devices to protect their occupants from the effects of heat. Sun-glasses were not a general issue to the troops and Colonel Gear argues that they may actually be harmful, because people who get used to them in the relatively non-glaring atmosphere of, say, Cairo, may suffer intensely when they go to the white sand areas of the Western Desert.

It is a well-deserved tribute that Colonel Gear pays to the hygiene officers and men of the Eighth Army. Their work was not dramatic. Its daily details involved matters to which many adopt an ostrich attitude; it was hard slogging against difficulties which can only be overcome by meticulous attention to detail and insistence on discipline. Apart from the maintenance of efficient sanitation among the British forces, the Hygiene Corps had to supervise the Bedouin and other peoples who fled to El Alamein and became such a sanitary danger behind the British lines that they had to be removed. They were faced, like their predecessors at Mosul and other places on the Tigris during 1914-18, with the task of cleaning up the gigantic heaps of refuse and filth left behind by the retreating enemy. But they had the advantage of wise direction and an efficient sanitary organization.

It is time that a just tribute be paid to these men, who guarded, by their unremitting care, the lives and health of the fighters .who saved. Egypt and India. Without them the British armies might have suffered the fate of the Germans and Italians. Like the Royal Army Service Corps, the Royal Army Ordnance Corps and all the other supply services, the Hygiene Corps provided an essential part of that basis of efficiency without which the best of fighting men cannot succeed.

G. LAPAGE.

\section{FOREST PRODUCTS}

A TTENTION has been directed in NATURE from time to time to the value and possible changes in the form of utilization of timber which plywood, one of the processes of lamination, renders possible. In an address before the Royal Society of Arts entitled "Forest Products", delivered on November $22,1943, \mathrm{Mr}$. W. A. Robertson, director of the Forest Products Research Laboratory, dealt with the results of research and the future possibilities $(J$. Roy. Soc. Arts, 92, Jan. 21, 1944). Great Britain will have ta depend for its supplies of soft woods on itself (a negligible factor for some years to come), the Continen't of Europe and on Canada.

As regards the forests of the British Empire, with the exception of Canada and Newfoundland the bulk lie in the tropies or sub-tropics, starting in the west with British Honduras and Guiana, on to the Gold
Coast and Nigeria, thence through Uganda, Kenya, Tanganyika across to India, Burma and Malaya, and one large forest block in the south of Australia. The total area of these tropical forests is very large. The present area accessible to exploitation is estimated at 330,000 sq. miles, which is less than the area of softwood forests in Canada (more than 550,000 sq. miles). The two types are not comparable. Whereas the softwood coniferous forests are mostly pure (that is, of one species only) or at most two or three, in the tropical forests hardwoods prevail ; species occur of varying degrees of hardness from very soft to the hardness of iron, and thirty or more species may be mixed together in a forest. To date but a few species have been in demand in Great Britain, and only a slightly larger number by the inhabitants of the countries in which the forests exist. Difficulties of commercial extraction under such conditions can be appreciated, also the failure to develop new markets owing to the mistaken policy of past administrations in insisting that the habits of the population, whether harmful to the forests and countryside generally and to a progressive development of the people concerned, should not be interfered with.

So far as difficulties of extraction are concerned, Mr. Robertson points out that the change is coming and that the new methods of use should permit of a much larger utilization. The first stage, he points out, is the change in the introduction of lamination usually associated with the term 'plywood' though, he says, lamination means much more than this. He explains it as follows in popular terms : "By the application of lamination we give up having to rely on the properties of chunks of timber as nature has given it to us with many defects and difficulties, and by arranging the timber in layers we balance defects with clear timber, we set off the weakness of timber in one direction by its strength in another and reduce the dimensional changes, i.e., the shrinkage and swelling. Thus a beam of $6^{\prime \prime} \times 3^{\prime \prime}$ made up of $\frac{1}{2}$ inch thick laminations can be about twice as strong as the same section cut out of solid timber of the same quality and a sheet of 3-plywood is $1 \frac{1}{2}$ times as strong in shear as a board of the same thickness, while its shrinkage and expansion is only onethirteenth of the plain wood across the grain".

The possible methods of utilization thus opened out will permit of the elimination in some cases, or the distribution in others, of inevitable defects, so that they shall not occur at places of maximum stress where their weakening effect would be most felt. It may be pointed out that the application of this contention is not universal, as the oak timbers in the roof of Westminster Hall and many churches and old barns in the south of England will prove. But it is beyond dispute that with the ever-increasing demand for timber products, the new methods will permit of the use of lower quality timber "in the lightly stressed parts of an assemblage and reserve the best quality for the highly stressed regions". Finally, it permits of the utilization of short lengths of timber, the most fruitful source of waste in the past. As Robertson says, it is no secret that lamination has allowed the survival of the wooden aircraft, for without it the spars of the necessary length would have been unprocurable. Finally, it is pointed out that between 1932 and 1937 the imports of plywood into Great Britain increased from roughly 5 million cubic feet a year to 13 million, and that several of the main producing countries had reached the limits of their home-grown resources'; the importance of 
this change in the use of wood is therefore selfevident. The more so, as has already been pointed out in NATURE, that it should enable secondary industries to be developed on the countryside in the Colonies.

Mr. Robertson also dealt briefly with the possibilities opening out in the chemical utilization of wood, in which considerable investigations have been carried out in America.

\section{FORTHCOMING EVENTS}

\section{Monday, June 5}

ROYal Geographical Soctery (at Kensington Gore, London, S.W.7), at 8 p.m. $\rightarrow$ Mr. J. A. Steers : "Coastal Preservation and Planning".

\section{Wednesday, June 7}

PHYSICAL SocteTY (COLOUR GROUP) (at the Royal Society of Arts, John Adam Street, Adelphi, London, W.C.2), at 4.30 p.m.-Dr. W. D out by a sub-Committee of the Optical Society of America on the Spacing of the Munsell Colours".

\section{Friday, June 9}

Royal ASTRonomical Societr (at Burlington House, Piccadilly, London, W.1), at 4.30 p.m. - Sir Harold Spencer Jones, F.R.S., and Mr. R. T. Cullen: "Preliminary Results of Tests of and Observations with the Reversible Transit Circle of the Royal Observatory, Greenwich"; Sir Arthu

ROYAL INSTITUTION (at 21 Albemarle Street, London, W.1), at 5 p.m.-Mr. Michael Graham: "Men and Science in the "Sea

\section{Saturday, June 10}

INSTITUTE OF PHYSICS (ELEOTRONICS GROOP) (at the Royal Society, Burlington House, Piccadilly, London, W.1), at 2.30 p.m.-Discussion on "Some Aspects of High 'Vacuum Technique, viz., High Vacuum Dr. B. P. Dudding).

\section{APPOINTMENTS VACANT}

APPLICATIONS are invited for the following appointments on or before the dates mentioned

GRADUATE to take SCIENCE, TECHNICAL DRAWING and MATHEMatics in the Newcastle Junior Technical School of Building Crafts - The Director of Education, City Educati

Newcastle upon Tyne, 2 (June 8).

Assistant Master qualifled to teach Practical Plane and Solid GEoverry for Engineering and Building Courses in the Plymouth Junior Technical School for Boys-The Director of Education, Education Offices, Cobourg Street, Plymouth (June 8).

LECTURER (man or woman) IN GEOGRAPHY AND MATHEMATICSThe Principal, Dudley and Staffs. Technical College, Dudley (June 9). ASSISTANT LECTURER (temporary) IN MATHEMATICS; and an ASSISTANT LECTURER (temporary) IN GEOGRAPHY-The Secretary, King's College, Strand, London, W.C.2 (June 9)

ing College, strand, London, W.c.2 (June 9). DEMONSTRAToR (man or woman) IN THF PHYsIOLOGY DEPARTMEN of Medicine for Women, 8 Hunter Street, Brunswick Square, London, W.C.1 (June 9)

.C.1 (June 9). MANAGER of the Manchester Waterworks Department -The Secretary, Waterworks Department, Town Hall, Manchester 2 (June 10).

INSPECrors (temporary) by the Board of Education (1) MECHANICAI OR ELECTRICAL ENGINERING (Reference No. C.2125A), (2) AERoNabTICAL Labour and National Service, Room 432, Alexandra House, (June 10). TEACHER (two, temporary) with qualifications in MATHEMATICS and PHYSICS for Service Training Courses (approximately Interand PHYsics for Service Training courses (approximately InterEssex Technical College and School of Art, Forest Road, WalthamEssex Technical College and 10 ).

stow, London, E.17 (June 10). HFFICER WTTH THE TECHNICAL DEVELOPMENT COMM Prise of the Holland War Agricultural Executive Committee-The Principal and Executive

(June 10). Mining and Technical Institute and Junior Technical School-The Director of Education, Education Department, County Hall, The Castle, Carmarthen (June 10)

ASSISTANT MASTER (Graduate or non-Graduate) with special qualiAcations in BoIlding SuBJECTS, MATHEMatics and ScIENCE, at the Hinckley Technical College-The Director of Education, County Education Office, Grey Friars, Leicester (June 10).

LECTURERs to take the following subjects for Evening Classes up to Matriculation standard: ElementTaRY MaTHEMATICS, Geography, ChEMISTRY, PHYSIOS, BIOLOGY, LOGIC-The Director of Education, The Polytechnic, Regent Street, London, W.1 (June 12)
SENIOR LECTURER IN BIOLOGY - The Clerk to the Governors, SouthEast Essex Technical College and School of Art, Longbridge Road, Dagenham, Essex (June 12).

GradUate AsSistant For Chemistry and Mathematios at the Sehool of Building of the East Ham Technical College-The Secretary
for Education, Education Office, Town Hall Annexe, Barking Road, East Ham, London, E.6 (June 12).

TEACHER (woman, full-time) of Hodsehold SOIENCE AND HYGIENE in the Domestic Sections of the Day Trade School and in Part-time Day Classes of the Cambridgeshire Technical School-The Education Secretary, Shire Hall, Cambridge (June 12).

LECTURER IN PSYCHOLOGY AND PRINCIPLES OF EDECATIONThe Principal, Gipsy Hill Training College, at Bankfield, Bingley, Yorks. (June 12).

DOCKYARD MANAGERS for service in the Sudan (must be fully trained Marine Engineers holding University engineering degrees, or
A.M.I.Mech.E. or A.M.I.N.A.)-The Ministry of Labour and National Service, Room 432, Alexandra House, Kingsway, London, W.C.2 (quoting Reference No. C.2148A) (June 14).

CHAIR OF NATURAI, PHILOSOPHY, United College, St. AndrewsThe Secretary, The University, St. Andrews (June 15).

The Secretary, The University, St. Andrews (June 15). Public Works Department-The Ministry of Labour and National Public Works Department-The Ministry of Labour and National (quoting Reference No. E.904A) (June 17).

ENTOMOLOGISTS in the Medical Department of Uganda, Northern Rhodesia, and the Tanganyika Territory, for general entomological work; with special emphasis on the investigation of tsetse fly and mosq; with special emphasis on the investigation of tsetse fiy and mosquito problems in the fleld as well as in the laboratory-The Kingsway, London, W.C.2 (quoting Reference No. F.2421A) (June 17), HEAD OF THE PHARMACY DEPARTMENT-The Registrar, Technical college, Sunderland (June 17).

INSTRUCTOR IN PRODUCTION ENGINEERING-The Registrar, Techical College, Sunderland (June 17)

nical College, Sunderland (June 17). LECTORER IN ENGINEERING in West Africa-The Ministry of Labour
and National Service, Room 432, Alexandra House, Kingsway, London, W.C.2 (quoting Reference No. E.836A) (June 21).

Physiorst for essential War work (work would include experience in various research departments of a North London firm specializing in optical instruments for scientific and industrial research and control)-The Ministry of Labour and National Service, Room 432, A.518XA) (June 21)

COMBUSTION AND RESEARCH ENGINEER by large organization, with headquarters at Glasgow-The Ministry of Labour and National Service, Room 432, Alexandra House, Kingsway, London, W.C.2 (quoting Reference No. C.2031XA) (July 1)

ASSISTANT LECTURER IN ENGINEERING-The Registrar, The University, Manchester 13 (July 1).

Assistant MEohanical ENGinene for the electrical branch of the Nigerian Government Public Works Department-The Secretary, Overseas Manpower Committee, Ministry of Labour and National Service, Alexandra House, Kingsway, London, W.C.2 (quoting Reference No. 1931)

Teacher of Scinnce (particularly Chemistry) aND Mathematios, and a TeACHER OF MATHEMATICS AND ENGINEERING SUBJECTS, at the Slough Junior Technical and Commercial School-The Secretary for Education, County Offices, Aylesbury, Bucks.

LECTORER (man or woman, temporary) FOR PHARMACEUTICAT SuBJEcrs to Ph.C. standard-The Principal, Birmingham Central Technical College, Suffolk Street, Birmingham 1.

LEOTURER IN GEOGRAPHY - The Registrar, The University, Reading. Mathematical Master or MIstress-The Acting Headmaster, Perse School, Cambridge.

LEOTURER IN GEOGRAPHY (Honours Degree and special interest in human side of Geography essential)-The Principal, Furzedown Training College, at 29 Corbett Ruad, Cathays Park, Cardiff. LECTURER (full-time) IN MECHANICAL ENGINEERING, and a MASTER
to teach SCIENCE and MATHEMATICS in the Junior Technical School for Boys-The Principal, Wimbledon Technical College, Gladstone Road, Wimbledon, London, S.W.19.

\section{REPORTS and other PUBLICATIONS (not included in the monthly Books Supplement)}

\section{Great Britain and Ireland}

Institution of Electrical Engineers. Report of the Council for the Year 1943-1944, presented at the Annual General Meeting on the
11th May 1944. Pp. 12. (London: Institution of Electrical Engineers.)
Board of Education. Principles of Government in Maintained Board of Education. Principles of Government in Maintained
Secondary Schools. (Cmd. 6523.) Pp. 10. (London: H.M. Stationery Secondary Schools. (Cmd. 6523.) Pp. 10. (London: H.M. Stationery
Office.) 2d. net. Scientists and Production. Pp. 8. (London : Association of Scientiflc Workers.) $3 d$.

Report on the Work of the National Organisers of the Association of Scientific Workers. Pp 16. (London: Association of Scientific
Workers.)

\section{Other Countries}

- Transactions of the San Diego Society of Natural History. Vol. 9, No. 34: Foraminifera from the Type Area of the Kreyenhagen Shale of California. By J. A. Cushman and S. S. Siegfus. Pp. 385-426+ plates 14-19. Vol. 9, No. 35 : Two New Wrens and a New Jay from Lower California, Mexico. By Laurence M. Huey. Pp. 427-434. Sonora, Mexico. By A. J. van Rossem. Pp. 435-436. Vol. 9, No. 37: A New Flea of the Genus Ceratophylius. By G. F. Augustson. Pp. 437-438. Vol. 9, No. 38: A Pleistocene Tortoise from the McKittrick Asphalt. By Loye Miller. Pp. 439-442. (San Diego, Calif. : San
Diego Society of Natural History.) 